\title{
Article \\ Detection of Cacao Mild Mosaic Virus (CaMMV) Using Nested PCR and Evidence of Uneven Distribution in Leaf Tissue
}

\author{
Alina S. Puig (1)
}

check for updates

Citation: Puig, A.S. Detection of Cacao Mild Mosaic Virus (CaMMV) Using Nested PCR and Evidence of Uneven Distribution in Leaf Tissue. Agronomy 2021, 11, 1842. https:// doi.org/10.3390/agronomy11091842

Academic Editors: Caterina Morcia, Giorgia Fedele and Salvatore Davino

Received: 30 July 2021

Accepted: 9 September 2021

Published: 14 September 2021

Publisher's Note: MDPI stays neutral with regard to jurisdictional claims in published maps and institutional affiliations.

Copyright: (C) 2021 by the author. Licensee MDPI, Basel, Switzerland. This article is an open access article distributed under the terms and conditions of the Creative Commons Attribution (CC BY) license (https:/ / creativecommons.org/licenses/by/ $4.0 /)$.
Subtropical Horticultural Research Station, USDA-ARS, Miami, FL 33158, USA; alina.puig@usda.gov

\begin{abstract}
Distribution of improved germplasm of Theobroma cacao is essential for meeting the increased demand for cocoa beans. In cacao, the introduction of new diseases is prevented by exchanging material through a national and international quarantine system. In 2020, virus symptoms were observed on plants in a quarantine greenhouse, and Cacao mild mosaic virus (CaMMV) was detected in one plant using published diagnostic primers. However, no virus was detected in other symptomatic plants. To address high pathogen diversity and low virus titer in recently infected plants, a nested PCR test was developed based on 15 CaMMV sequences from Trinidad and Puerto Rico. The test was validated on a subset $(n=30)$ of plants in the greenhouse, of which 29 tested positive. Most infections are thought to have occurred during the later stage of the quarantine period, possibly due to spread by mealybugs. However, phylogenetic analysis revealed the presence of three strains, suggesting that it was introduced on scionwood from multiple sources. Results of PCR assays on different leaf tissues indicate that the virus is unevenly distributed and that petiole tissue should be used in molecular diagnostics. The movement of infected scionwood is a major dissemination pathway for CaMMV but can be managed through careful screening.
\end{abstract}

Keywords: Theobroma cacao; cacao trinidad virus; quarantine; molecular diagnostics; systemic infection; badnavirus

\section{Introduction}

Cacao mild mosaic virus (CaMMV) causes mosaic and chlorosis symptoms on leaves and mottling on pods of cacao (Theobroma cacao L.). It is transmitted by several mealybug species and the use of infected material during grafting. CaMMV, previously known as cacao trinidad virus strain A, was first identified in 1943 [1], and infected plants showed $7-33 \%$ lower annual yield [2,3]. It was believed to have been eradicated following a government-mandated tree removal program in the 1950s until infected material was found in the International Cocoa Quarantine Centre-Reading in Reading, UK, in 2007 [4]. CaMMV was recently reported in Puerto Rico [5] and confirmed in Brazil [6], indicating that the virus is more widespread than originally thought.

Development and distribution of improved cacao germplasm are essential for meeting increased demand for cocoa beans and safeguarding genetic diversity. However, material exchange is restricted due to the risk of introducing new pests and diseases. In 1955, the U.S. Department of Agriculture (USDA) initiated a quarantine and distribution program for cacao germplasm, based out of the Subtropical Horticulture Research Station (SHRS) in Miami, FL, to increase the diversity available for plant breeding research [7]. In addition to a quarantine greenhouse, SHRS is the backup collection site for the USDA Agriculture Research Service (ARS) National Plant Germplasm System (NPGS) cacao germplasm maintained by the Tropical Agricultural Research Station (TARS) in Mayaguez, PR. Following a two-year containment, material is indexed for viruses by grafting onto susceptible indicator 'Amelonado' rootstock and monitoring it for symptom development over two months, a bioassay developed for cacao swollen shoot virus disease complex (CSSVD) [8]. However, CaMMV is characterized by comparatively mild symptoms and a variable latent period, both of which are capable of affecting the onset of symptoms in new growth. 
Viruses have been confirmed in cacao on every continent where the crop is cultivated (North America, South America, Asia, and Africa) [1,9-13]. Most cacao viruses that have been molecularly characterized are in the Badnavirus genus $[10,11,14,15]$, except for Cacao yellow mosaic virus [16] and Cacao necrosis virus [17], which are in the Tymovirus and Nepovirus genera, respectively $[12,18]$. The genome of CaMMV contains the three open reading frames (ORFs) found in all members of the Badnavirus genus, plus a fourth referred to as ORFY [14]. Diagnostic PCR primers for cacao infecting badnaviruses are commonly designed for the region of ORF3 corresponding to the putative movement protein, due to this area being highly conserved among species [19]. Additional knowledge of virus distribution around the globe and the development of additional detection methods will improve the effectiveness of quarantine procedures for T. cacao.

In 2020, a greenhouse inspection revealed plants with leaf mosaic and vein-banding characteristics of badnavirus infection (Figure 1). This manuscript describes a sensitive, nested PCR test for detection of CaMMV in symptomatic and asymptomatic cacao plants and a quali-quantitative PCR for localization of virus in host tissue that provides valuable information on host-pathogen interaction.
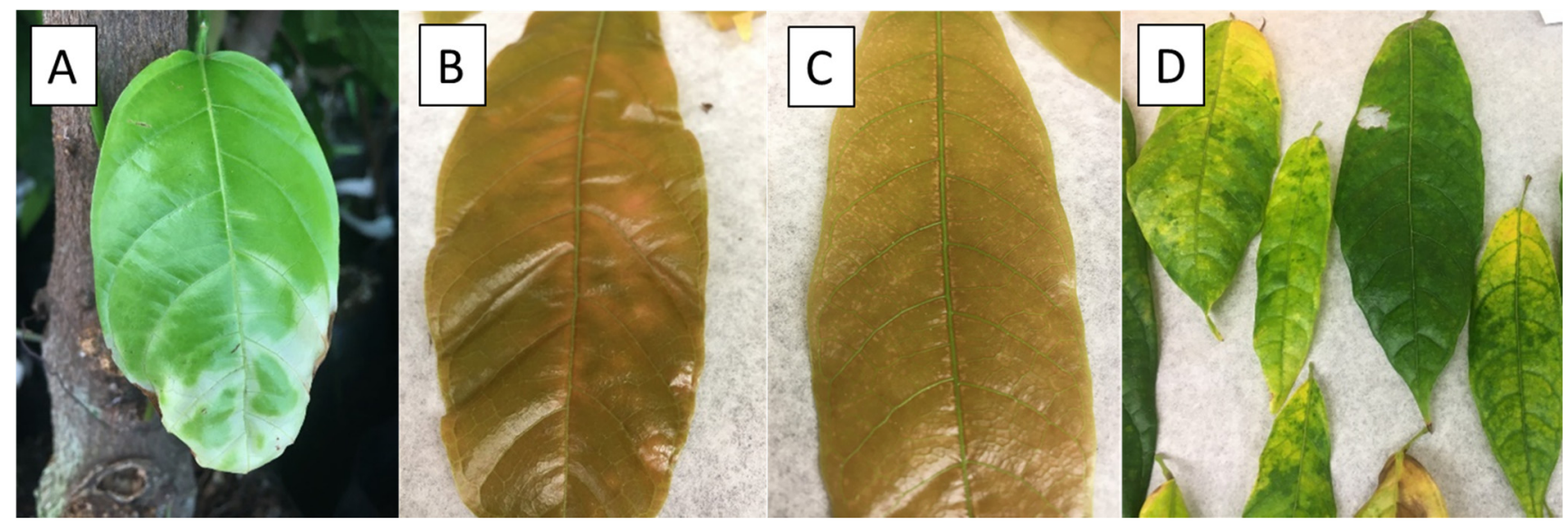

Figure 1. Cacao (Theobroma cacao L.) leaves observed in September 2020 with virus symptoms such as (A) white vein banding (B) red vein banding (C) flecking (D) mosaic.

\section{Materials and Methods}

\subsection{Confirmation of CaMMV}

Initial confirmation of CaMMV in quarantine material in Miami, FL was done using the primer pair CaMMV-1112F 5'-TACGGAGACTGTGACTCAACCA-3' /CaMMV-1959R $5^{\prime}$-GTTTGGTAGGTTCCTTGTATCTGC-3' ${ }^{\prime}$ as described in Puig et al. [5] (Table 1). DNA was extracted from $60 \mathrm{mg}$ fresh (or $30 \mathrm{mg}$ lyophilized) leaf tissue from the leaf base using the Qiagen DNeasy Plant Mini kit (Qiagen, Valencia, CA, USA) with two final elutions (50 $\mu \mathrm{L}$ each). Five to ten $\mu \mathrm{L}$ of DNA was used as template in a $25 \mu \mathrm{L}$ PCR reaction. Amplification was visualized on a $1 \%$ agarose gel, and the amplified product was purified with the Qiaquick PCR Purification Kit (Qiagen, Valencia, CA, USA) and then bi-directionally Sanger sequenced by Eurofins Genomics (Louisville, KY, USA). For identification, forward and reverse sequences were aligned and edited using Geneious 11.1.2 (Biomatters Ltd., Auckland, New Zealand) and analyzed in BLASTn.

\subsection{Primer Design}

To address the non-specific amplification and low sensitivity of the test described above, along with the high genetic variability of the pathogen, several pairs of degenerate primers were designed for the movement protein-coat protein $(\mathrm{MP}-\mathrm{CP})$ genome region of CaMMV for use in a nested PCR. This was done using Primer3 in Geneious Prime 2020 software based on a multiple alignment of 15 CaMMV sequences (Figure 2). Four of these 
were publicly available sequences from Trinidad (KX276640) and Puerto Rico (MT253655, MT262888, and MT262890), one was obtained from Miami FL during this study, and ten were from symptomatic plants in Puerto Rico (Puig, unpublished). Except for KX276640, all sequences used in primer design were amplified as described above.

Table 1. Primer pairs used for CaMMV detection and localization in this study.

\begin{tabular}{|c|c|c|c|c|}
\hline Comments & Primer Name & Sequence $\left(5^{\prime}-3^{\prime}\right)$ & Length & Amplicon (bp) \\
\hline $\begin{array}{l}\text { Nested PCR } \\
\text { (outer) }\end{array}$ & $\begin{array}{l}\text { Mia1145F } \\
\text { Mia1926 }\end{array}$ & $\begin{array}{c}\text { YAACTTTGAGGACCAGATC } \\
\text { YCTAAGTATCCARCTYCTTCCAAGR }\end{array}$ & $\begin{array}{l}19 \mathrm{bp} \\
25 \mathrm{bp}\end{array}$ & 806 \\
\hline $\begin{array}{l}\text { Nested PCR } \\
\quad \text { (inner) }\end{array}$ & $\begin{array}{l}\text { Mia1396F } \\
\text { Mia1876R }\end{array}$ & $\begin{array}{l}\text { ACCGTGTCTAYCAGCACTGGA } \\
\text { CTGGRATWGCTCTTACKCCATGW }\end{array}$ & $\begin{array}{l}21 \mathrm{bp} \\
23 \mathrm{bp}\end{array}$ & 503 \\
\hline Semi-quantitative, virus-specific & $\begin{array}{l}\text { Mia1396F } \\
\text { Mia1667R }\end{array}$ & $\begin{array}{c}\text { ACCGTGTCTAYCAGCACTGGA } \\
\text { GACCACCGTCAGCCAGAC }\end{array}$ & $\begin{array}{l}21 \mathrm{bp} \\
18 \mathrm{bp}\end{array}$ & 289 \\
\hline $\begin{array}{l}\text { Semi-quantitative, host-specific } \\
\text { (for standardization) }\end{array}$ & $\begin{array}{l}\text { TcACTF } \\
\text { TcACTR }\end{array}$ & $\begin{array}{l}\text { CAGACTTTGAGTTCACTTGACACAG } \\
\text { AGTGTCTGGATTGGAGGATCTATCT }\end{array}$ & $\begin{array}{l}25 \mathrm{bp} \\
25 \mathrm{bp}\end{array}$ & $\sim 200$ \\
\hline Original diagnostic [5] & $\begin{array}{l}\text { CaMMV-1112F } \\
\text { CaMMV-1959R }\end{array}$ & $\begin{array}{l}\text { TACGTAACCATCATTGATGC } \\
\text { CTTCTTTACGTTCAATGTCC }\end{array}$ & $\begin{array}{l}20 \mathrm{bp} \\
20 \mathrm{bp}\end{array}$ & 867 \\
\hline
\end{tabular}

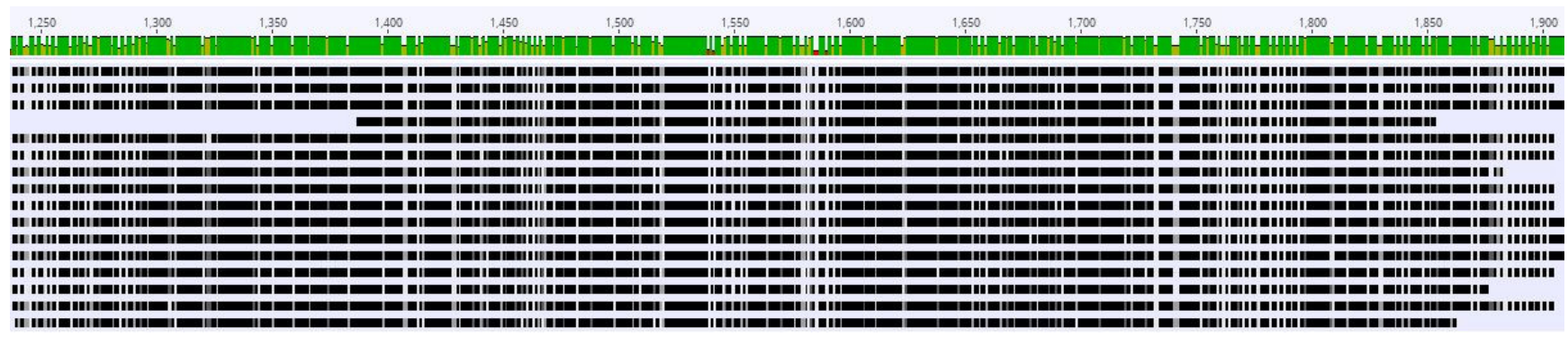

Figure 2. Multiple alignments of the coat protein-movement protein (CP-MP) region of 15 CaMMV isolates recovered from infected cacao (Theobroma cacao L.) used in degenerate primer design. Light areas indicate nucleotide differences among sequences.

\subsection{Nested PCR}

For nested PCR, the initial reaction was $20 \mu \mathrm{L}$ with $10 \mu \mathrm{L}$ Sigma-Aldrich@ JumpStart $^{\mathrm{TM}}$ REDTaq $^{\circledR}$ ReadyMix $^{\mathrm{TM}}, 7.6 \mu \mathrm{L}$ molecular grade water, $0.8 \mu \mathrm{L}$ of each $10 \mathrm{uM}$ primer (Mia1145F and Mia1926R), and $0.8 \mu \mathrm{L}$ of DNA template. Amplification conditions were an initial 2 min step at $94{ }^{\circ} \mathrm{C}$, followed by 23 cycles of $94{ }^{\circ} \mathrm{C}(25 \mathrm{~s}), 34^{\circ} \mathrm{C}(25 \mathrm{~s})$, and $72{ }^{\circ} \mathrm{C}$ ( $1 \mathrm{~min})$, and then a final extension at $72^{\circ} \mathrm{C}$ for $12 \mathrm{~min}$.

The final reaction was also with a $20 \mu \mathrm{L}$ volume as described above, with primers Mia1396F and Mia1876R and $0.8 \mu \mathrm{L}$ of amplified PCR product as the template. Amplification conditions were initial 2 min step at $94{ }^{\circ} \mathrm{C}$ followed by 37 cycles of $94{ }^{\circ} \mathrm{C}(20 \mathrm{~s}), 53{ }^{\circ} \mathrm{C}$ (20 s), and $72{ }^{\circ} \mathrm{C}(1 \mathrm{~min})$, and then a final extension at $72{ }^{\circ} \mathrm{C}$ for $10 \mathrm{~min}$.

\subsection{Detection of CaMMV in Theobroma cacao}

Performance of the newly developed CaMMV nested PCR assay was assessed on a subset of 30 plants held in the SHRS cacao quarantine greenhouse. They had been imported from England $(n=21)$, Costa Rica $(n=7)$, Ecuador $(n=1)$, and Dominican Republic $(n=1)$ and were scheduled to be released in 2020 after having spent a minimum of 3 years in quarantine. Plants were examined visually for the presence of viral symptoms and categorized as symptomatic or asymptomatic. From each plant, three leaves were collected from different parts of the canopy for testing. DNA extractions and nested PCRs were performed as described above, and amplification was visualized on a 1\% agarose gel. Amplified samples were sequenced and edited as described previously. Presence of virus in leaf samples was confirmed following BLASTn analysis. 


\subsection{Phylogenetic Comparison}

To determine the diversity of virus strains detected in the USDA-ARS Cacao Quarantine Greenhouse, MP-CP sequences were used to build a phylogenetic tree in MEGA X [20], with sequences aligned using MUSCLE algorithm [21]. The Tamura 3-parameter model was chosen using the MEGA X models function to assess various nucleotide substitution models [22]. Initial trees for the heuristic search were generated automatically by applying Neighbor-Join and BioNJ algorithms to a matrix of pairwise distances estimated using the Tamura 3 parameter model with a discrete Gamma distribution $(5$ categories $(+G$, parameter $=1.2132)$ ) and then choosing the topology with a superior log likelihood value. Tree branch lengths were measured in the number of substitutions per site.

Codon positions included were $1 \mathrm{st}+2 \mathrm{nd}+3 \mathrm{rd}+$ Noncoding. Any positions with less than $95 \%$ site coverage were eliminated, meaning that fewer than $5 \%$ alignment gaps, missing data, and ambiguous bases were allowed at any position (partial deletion option). There were 60 nucleotide sequences and 355 positions in the final dataset.

Sequences of cacao-infecting Badnaviruses available in GenBank were included for comparison. These include strains of Cacao mild mosaic virus from Trinidad (KX276640) and Puerto Rico (MT253655), Cacao Sri Lanka Bacilliform Virus (MF642736), Cacao yellow vein banding virus (KX276641), and members of the complex known as Cacao swollen shoot virus (CI286, KX592584; Ghana J GWR198J-13, MF642721; Togo A Gha25-15, MF642716). Clade stability was assessed by bootstrap analysis with 1000 replicates.

\subsection{Quantification of Virus Titer in Different Leaf Tissues}

To determine tissue localization of CaMMV in plant leaves, 12 consecutive leaves from a single branch were sampled from a plant that had tested positive for the virus using nested PCR as described above. Leaves were numbered starting with the youngest, and each leaf was dissected into five different components: petiole, midrib, side veins, lamina (base), and lamina (apex). DNA was extracted from $35 \mathrm{mg}$ of fresh tissue as described previously and concentration was estimated using Qubit.

To quantify virus titer in each tissue type, two separate PCRs were run from each subsample (leaf $\times$ tissue type). One PCR used CaMMV-specific primers Mia1396F and Mia1667R, and the other used primers TcACTF and TcACTR, which amplify a 200 bp fragment of an actin gene from T. cacao. This housekeeping gene is used as an internal standard in RNAseq studies and has been shown to be present at a rate of 1 gene copy per cell in all cacao genotypes evaluated.

For each primer pair, the reaction was $20 \mu \mathrm{L}$ volume with $0.8 \mathrm{ng}$ DNA as the template. Amplification conditions were an initial 2-minute step at $94{ }^{\circ} \mathrm{C}$ followed by 38 cycles at $94{ }^{\circ} \mathrm{C}(20 \mathrm{~s}), 57^{\circ} \mathrm{C}(20 \mathrm{~s})$, and $72{ }^{\circ} \mathrm{C}(50 \mathrm{~s})$, and then a final extension at $72{ }^{\circ} \mathrm{C}$ for $8 \mathrm{~min}$.

All PCR products were purified and then quantified using Qubit. CaMMV titer in each subsample was calculated as the concentration of DNA following amplification with virus-specific primers, divided by DNA concentration following amplification with cacao-specific primers.

virus titer $=\frac{\text { concentration }(\mathrm{ng} / \mu \mathrm{L}) \text { of PCR product amplified with Mia1396F } / \text { Mia1667R }}{\text { concentration }(\mathrm{ng} / \mu \mathrm{L}) \text { of PCR product amplified with TcACTF } / \text { TcACTR }}$

Differences in virus titer among the five tissue types were assessed by conducting an analysis of variance (ANOVA) in SAS 9.4 (SAS Institute 2016). Means were separated using Tukey-Kramer Comparison lines for the least squares means of the isolates.

\section{Results}

\subsection{Confirmation of CaMMV}

Symptomatic leaves from five plants were tested using CaMMV diagnostic primers, and PCR amplification was observed in three of them. One sample yielded a fragment 95\% and 96.2\% identical to strains from Trinidad (KX276640) and Puerto Rico (MT262889), respectively. Symptomatic leaves from two other plants yielded a 500-900 bp sequence 
that was $>99 \%$ identical to a region of the T. cacao genome on chromosome I (LT594788). No amplification was observed in the negative control.

\subsection{Primer Design and Nested PCR}

Several pairs of degenerate primers were designed to amplify the MP-CP region, based on sequences from 15 isolates of CaMMV (Supplementary File S2). The outer (Mia1145F/Mia1926R) and inner (Mia1396F/Mia1876R) pairs that produced the most consistent results are shown in Table 1. The external pair amplifies the 1145-1926 bp region of the publicly available CaMMV genome (KX276640), and the internal pair amplifies the 1396-1876 bp region. $503 \mathrm{bp}$ was the predicted length of the amplified DNA product.

Due to variations in sequence length, the external forward primer (Mia1145F) was based on 7-8 sequences (Figure 3A) and external reverse primer (Mia1926R) was based on $4-5$ sequences (Figure $3 \mathrm{~B}$ ). Inner primers were designed based on all 15 sequences (Figure 3C,D). Following the second round of amplification, a fragment of $\sim 500 \mathrm{bp}$ was seen on the gel. Amplified fragments were sequenced using Mia1396F/Mia1876R primers.

(A) Forward external primer, Mia1145F

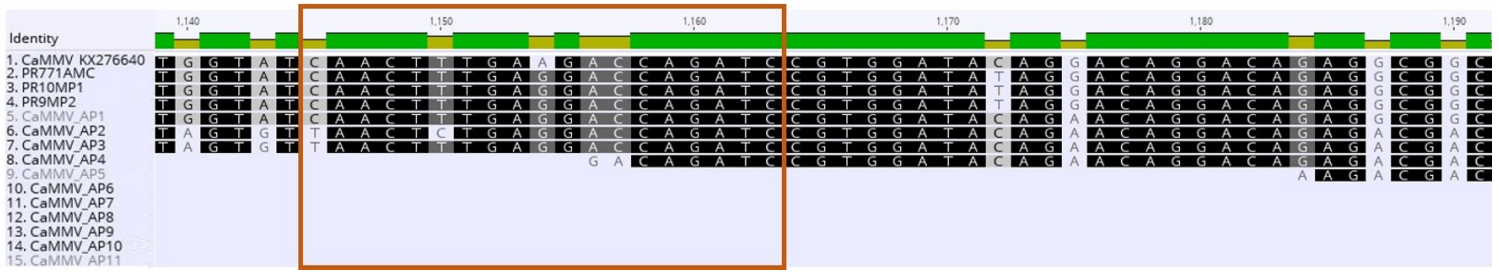

(B) Reverse external primer, Mia1926R

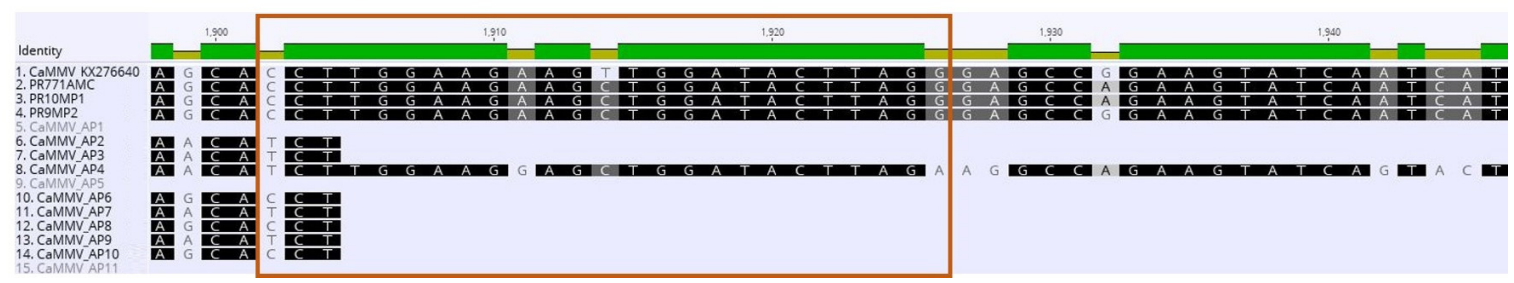

(C) Forward internal primer, Mia1396F

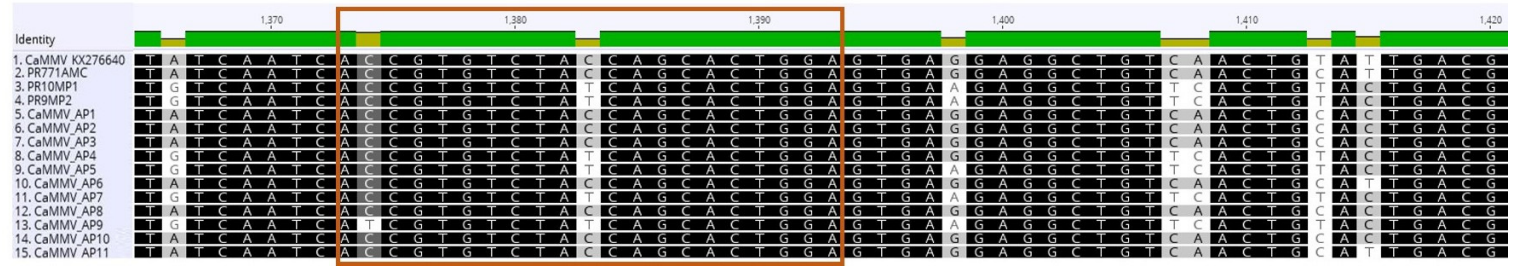

(D) Reverse internal primer, Mia1876R

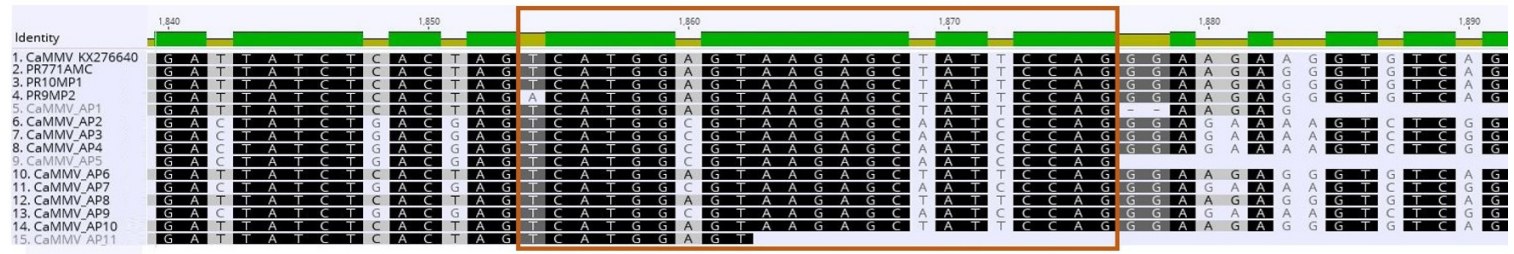

Figure 3. Alignment of partial sequences of the movement protein-coat protein region of Cacao mild mosaic virus (CaMMV) strains. The red frame indicates the annealing sites of the (A) Forward external primer, Mia1145F, (B) Reverse external primer, Mia1926R, (C) Forward internal primer, Mia1396F, and (D) Reverse internal primer, Mia1876R. Light areas indicate nucleotide differences among sequences. 


\subsection{Detection of CaMMV in Theobroma cacao}

The nested PCR was carried out on 30 symptomatic and asymptomatic plants in postentry quarantine to determine infection with CaMMV. Twenty-nine of these tested positive for CaMMV, including all asymptomatic plants $(100 \%, n=10)$ and 19 symptomatic plants $(95.7 \%, n=20)$. Infection was determined based on amplification of a $\sim 500 \mathrm{bp}$ fragment and homology of the resulting sequence to previously obtained CaMMV sequences. No amplification was observed in any of the no-template controls. A representative subset of the 53 sequences generated in this study were deposited in GenBank and are publicly available (Table 2).

Table 2. A subset of the sequences of the coat protein-movement protein (CP-MP) region of Cacao mild mosaic virus generated in this study and deposited in Genbank. Sequences were amplified using a nested PCR (outer primers: Mia1145F/Mia1926R; inner primers: Mia1396F/Mia1876R) and sequenced with the internal primers. The letters designate from which leaf on the tree the sequence originated $(\mathrm{a}=$ leaf $1, \mathrm{~b}=$ leaf $2, \mathrm{c}=$ leaf 3$)$.

\begin{tabular}{ccccc}
\hline Isolate & \multicolumn{1}{c}{ Species } & Host & Origin & GenBank \\
\hline $83 a$ & Cacao mild mosaic virus & Theobroma cacao & USA & MZ325886 \\
$201 \mathrm{a}$ & Cacao mild mosaic virus & Theobroma cacao & USA & MZ325887 \\
$200 \mathrm{~b}$ & Cacao mild mosaic virus & Theobroma cacao & USA & MZ325888 \\
$199 \mathrm{a}$ & Cacao mild mosaic virus & Theobroma cacao & USA & MZ325889 \\
$88 \mathrm{a}$ & Cacao mild mosaic virus & Theobroma cacao & USA & MZ325890 \\
$183 \mathrm{c}$ & Cacao mild mosaic virus & Theobroma cacao & USA & MZ325891 \\
$186 \mathrm{c}$ & Cacao mild mosaic virus & Theobroma cacao & USA & MZ325892 \\
$194 \mathrm{c}$ & Cacao mild mosaic virus & Theobroma cacao & USA & MZ325893 \\
$197 b$ & Cacao mild mosaic virus & Theobroma cacao & USA & MZ325894 \\
$187 c$ & Cacao mild mosaic virus & Theobroma cacao & USA & MZ325895 \\
200c & Cacao mild mosaic virus & Theobroma cacao & USA & MZ325896 \\
202c & Cacao mild mosaic virus & Theobroma cacao & USA & MZ325897 \\
\hline
\end{tabular}

\subsection{Phylogenetic Comparison}

Evolutionary relationships among virus isolates found on T. cacao were inferred in MEGA X using the Maximum Likelihood method and Tamura 3-parameter model [23] for sequences of the coat protein-movement protein region. The tree with the highest log likelihood (-2594.00) is shown in Figure 4.

The 53 CaMMV sequences generated in this study clustered into three primary groups, with the largest group sharing approximately $95.3 \%$ (193aE)-95.8\% (94c) nucleotide sequence identity with the reference isolate from Trinidad (CaMMV_ref) as determined following BLASTn analysis. The next largest group $(n=11)$ shared approximately $96.1 \%$ (193aF)-95.7\% (83a) nucleotide sequence identity with the Trinidad strain, while the other group $(n=10)$ was more divergent, sharing only $84.8 \%$ (194c) to $86 \%$ (186c) identity.

All sequences $(n=53)$ obtained in this study have names composed of numbers followed by letters that designate the leaf they were detected in $(a=$ leaf $1, b=$ leaf 2 , $\mathrm{c}=$ leaf 3). Multiple sequences from leaf 193a were provided by the sequencing company. These are followed by a capital A, B, C, D, E, or F to differentiate them. Sequences of seven cacao-infecting Badnaviruses available in GenBank were included for comparison. These include strains of Cacao mild mosaic virus (CaMMV prefix), members of the Cacao swollen shoot virus disease complex (CSSV prefix), Cacao Sri Lanka bacilliform virus (CSLBV), and Cacao yellow vein banding virus (CYVBV). 


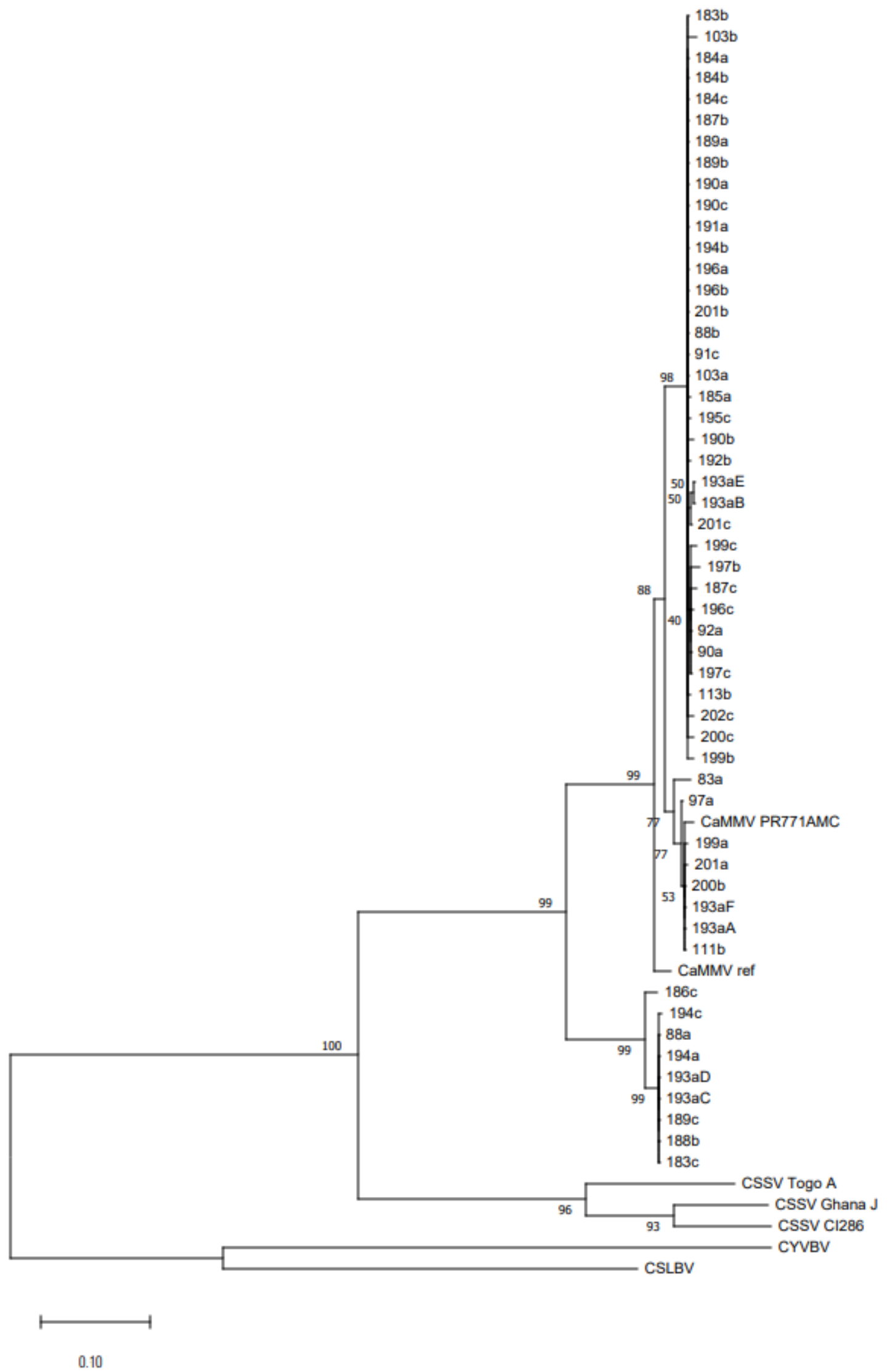

Figure 4. Phylogenetic tree constructed using the predicted amino acid sequences of the coat protein using maximumlikelihood method and neighbor-joining algorithm provided in MEGAx. Sequences of cacao-infecting badnaviruses 
available in GenBank were included for comparison. These include strains of Cacao mild mosaic virus (CaMMV prefix), Members of the cacao swollen shoot virus disease complex (CSSV prefix), Cacao Sri Lanka Bacilliform Virus (CSBV), and Cacao yellow vein banding virus (CYVBV). All sequences obtained in this study have names composed of numbers followed by letters that designate the leaf they were found in $(a=$ leaf $1, b=$ leaf $2, c=$ leaf 3). Multiple sequences from leaf 193a were provided by the sequencing company. These are followed by a capital A, B, C, D, E, or F to differentiate them. Numbers shown above branches indicate the percentage of replicate trees in which the associated taxa clustered together in the bootstrap test (1000 replicates).

\subsection{Quantification of Virus Titer in Different Leaf Tissues}

Concentrations of DNA following amplification with virus and host-specific primers were compared in petiole, midrib, sidevein, lamina (base), and lamina (apex) to determine virus localization within leaves and identify the best tissues for diagnostic testing (Supplementary File S1). In petioles, virus concentration exceeded host concentration in 8 of 12 leaves tested. This number fell to 4 of 12 for sidevein and midrib samples, and 1 of 12 in each laminar tissue category (apex and base) (Figure 5).
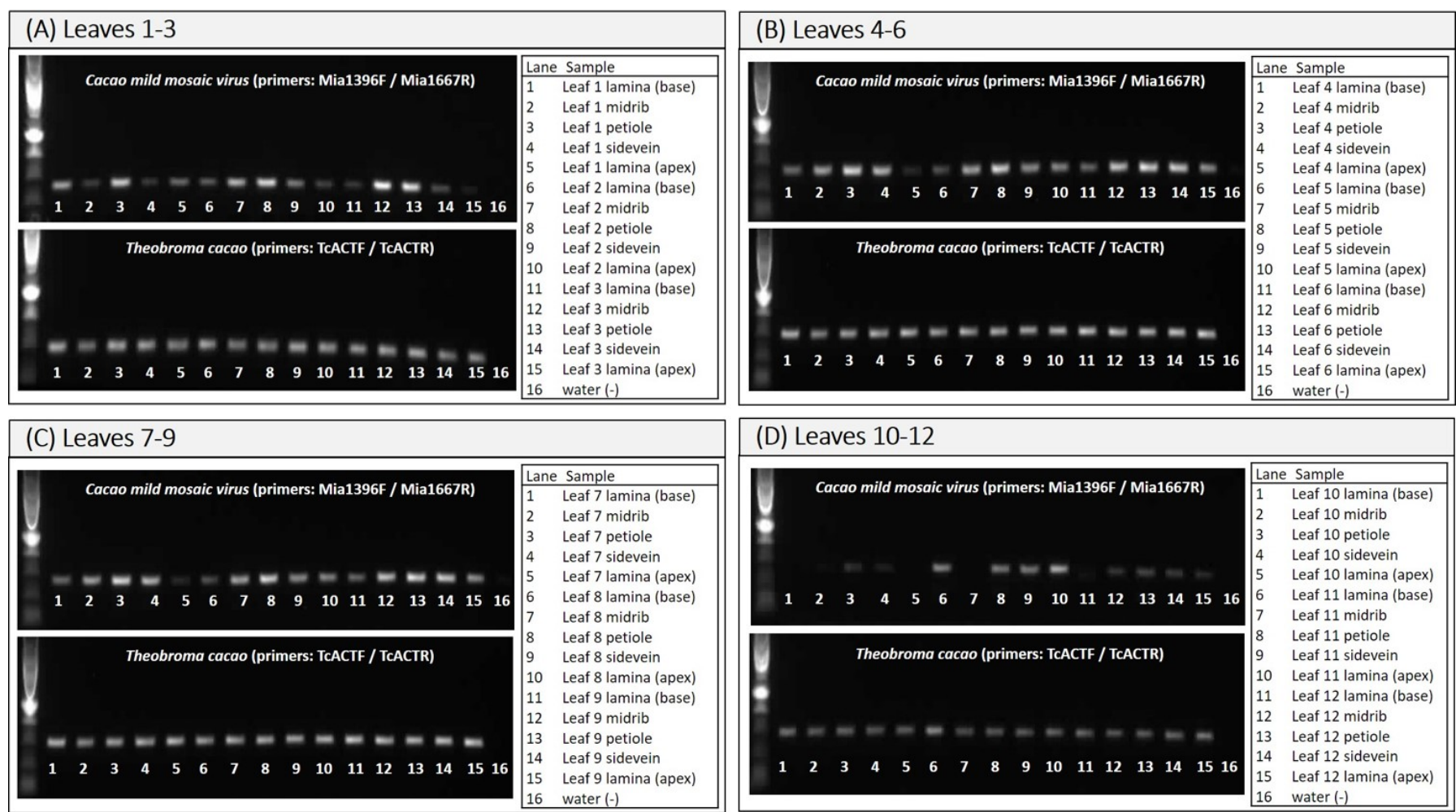

Figure 5. Amplification products using virus-specific (top rows) and cacao-specific (bottom rows) primers in leaf tissues (lamina (base), midrib, petiole, sidevein, lamina (apex)). Intensity of amplicon corresponds to PCR product concentration/titer (data in File S1).

Virus concentrations, standardized by concentration of host housekeeping gene, differed among tissue types $(p<0.02, F=3.11)$, ranging from $0.36 \mathrm{ng} / \mathrm{ul}( \pm 0.34)$ in basal laminar tissue to $1.01 \mathrm{ng} / \mathrm{ul}( \pm 0.49)$ in petioles. However, these differences were only statistically significant between petiole and lamina (base) $(p<0.014)$. Differences in virus concentration between petiole and lamina (apex) were somewhat significant $(p<0.075)$ (Figure 6). 


\section{Relative virus concentration in leaf tissues}

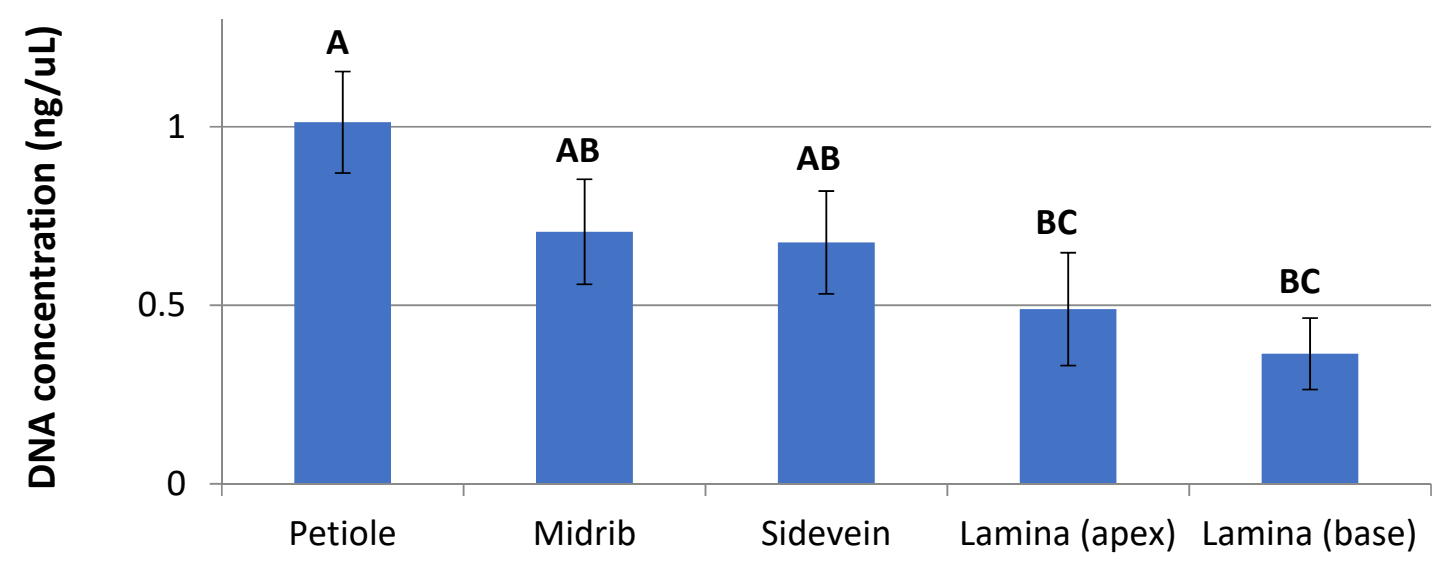

Figure 6. Mean DNA concentration of Cacao mild mosaic virus (CaMMV) in different cacao (Theobroma cacao L.) leaf tissue types following amplification of $0.8 \mathrm{ng}$ DNA extract with species-specific primers Mia1396F/Mia1667R. Columns with same letters above the bars are not significantly different $(p \leq 0.05)$.

\section{Discussion}

Fifty-three virus sequences were obtained from 29 plants in the post-entry quarantine SHRS greenhouse, using the newly developed nested PCR test. The high incidence (96.7\%) of infection is attributed to severe mealybug outbreaks in 2017-2019, which are thought to have led to many plants becoming infected during the quarantine period. However, phylogenetic analysis revealed the presence of three different strains, suggesting that CaMMV may have been introduced on multiple sticks of scionwood from multiple sources and/or in several events.

Young growing plants that become infected with CaMMV by mealybugs can have long latent periods, taking 40-178 days for symptoms to develop [24], decreasing the effectiveness of plant removal to control disease spread. In addition, virus titers are thought to be higher in plants around the time that the first symptoms appear following infection, compared with symptomatic plants that have been infected for longer periods of time [25]. Although mealybugs are slow-moving and only walk short distances, they can become infective in as little as 35 min of feeding on an infected plant [25]. For this reason, aggressive vector control is essential.

Although this study confirms viral infection in the T. cacao plants in post-entry quarantine, and the presence of multiple strains, whole-genome sequencing is needed to definitively assess the genetic relationship among them. Many plants contained multiple strains of CaMMV, consistent with findings on CSSVD in West Africa $[10,14]$, and were suggestive of high genetic variability in the Americas. This means some strains may not be detectable with these primers, and the current bioassay, where scionwood is grafted onto an indicator plant ('ICS6' or 'Amelonado' rootstock), should still be used alongside molecular tools for pathogen detection.

There is no treatment for plants infected with CaMMV. Heat treatment of infected scionwood to inactivate the virus was attempted by Posnette [1], but it was not successful. Destruction of infected plants is currently recommended to prevent them from serving as inoculum reservoirs. 


\section{Conclusions}

This research describes a sensitive, nested PCR test for the detection of CaMMV in symptomatic and asymptomatic cacao plants, whose effectiveness was shown on cacao plants in post-entry quarantine. The primers target a portion of the coat protein-movement protein gene and successfully detected three distinct strains of the virus. This diagnostic test is a valuable tool for CaMMV detection and can be used to index germplasm before releasing it from quarantine alongside the traditional bioassay using susceptible rootstock. Detailed surveys are needed throughout the Western Hemisphere to better understand the prevalence and distribution of viruses on cacao.

Supplementary Materials: The following are available online at https:/ /www.mdpi.com/article/ 10.3390/agronomy11091842/s1, File S1: DNA concentration of PCR product amplified using virusspecific and host-specific primers in different leaf tissues, File S2: Additional primers designed during this study.

Funding: This research received no external funding.

Data Availability Statement: A representative subset of sequences have been deposited in GenBank and are publicly available. DNA concentrations of amplicons used to quantify virus distribution in leaves are available online at https:/ / www.mdpi.com/article/10.3390/agronomy11091842/s1.

Acknowledgments: Thank you to Sarah Wurzel and Wil Quintanilla (USDA-ARS, Miami FL) for their technical assistance. Thank you, also, to Brian Irish, Bryan Bailey, and Shahin Ali for critical reviews of this manuscript.

Conflicts of Interest: The author declares no conflict of interest.

\section{References}

1. Posnette, A. Virus diseases of cacao in Trinidad. Trop. Agric. 1944, 21, 105-107.

2. Cope, F. Statistical studies in the effects of virus infection upon yield in clonal cacao. Rep. Cacao Res. 1945-1951 1953, 4, 126-129.

3. Swarbrick, J. Cacao virus in Trinidad. Trop. Agric. 1961, 38, 245-249.

4. Sreenivasan, T. The Enigma of the ICS 76 Plants at Reading, UK; International Cocoa Quarantine Center: Reading, UK, 2009.

5. Puig, A.; Ramos-Sobrinho, R.; Keith, C.; Kitchen, N.; Gutierrez, O.; Goenaga, R.; Brown, J.K. First Report of Cacao Mild Mosaic Virus Associated with Symptomatic Commercial Cacao (Theobroma cacao) Trees in Puerto Rico. Plant Dis. 2020, $104,3089$. [CrossRef]

6. Ramos-Sobrinho, R.; Ferro, M.M.; Nagata, T.; Puig, A.S.; Von Keith, C.; Britto, D.S.; Gutierrez, O.A.; Marelli, J.-P.; Brown, J.K. Complete genome sequences of three newly discovered cacao mild mosaic virus isolates from Theobroma cacao L. in Brazil and Puerto Rico and evidence for recombination. Arch. Virol. 2021, 166, 2027-2031. [CrossRef]

7. Fisher, H.; Haun, J.; Ackerman, W. Cacao seedling production and distribution through plant quarantine. Cacao 1960, 5, 1-8.

8. Thresh, J. Quarantine arrangements for intercepting Cocoa material infected with West African viruses. Plant Prot. Bull. FAO 1960, 8, 89-92.

9. Posnette, A.; Palma, M. Observations on cacao on the Paria peninsula, Venezuela. Trop. Agric. 1944, 21, $130-132$.

10. Muller, E.; Ravel, S.; Agret, C.; Abrokwah, F.; Dzahini-Obiatey, H.; Galyuon, I.; Kouakou, K.; Jeyaseelan, E.; Allainguillaume, J.; Wetten, A. Next generation sequencing elucidates cacao badnavirus diversity and reveals the existence of more than ten viral species. Virus Res. 2018, 244, 235-251. [CrossRef]

11. Probowati, W.; Somowiyarjo, S.; Hartono, S. Molecular characterization of Mosaic Virus from the cocoa trees showing mosaic symptoms in Yogyakarta, Indonesia. Biodiversitas J. Biol. Divers. 2019, 20, 3698-3704. [CrossRef]

12. Thresh, J. The control of cacao swollen shoot disease in West Africa: A review of the present situation. Tech. Bull. West Afr. Cocoa Res. Inst. 1958, 4, 36.

13. Muller, E. Cacao Swollen Shoot Virus (CSSV): History, biology, and genome. In Cacao Diseases; Springer: Cham, Switzerland, 2016; pp. 337-358.

14. Chingandu, N.; Sreenivasan, T.N.; Surujdeo-Maharaj, S.; Umaharan, P.; Gutierrez, O.A.; Brown, J.K. Molecular characterization of previously elusive badnaviruses associated with symptomatic cacao in the New World. Arch. Virol. 2017, 162, 1363-1371. [CrossRef]

15. Chingandu, N.; Dongo, L.; Gutierrez, O.A.; Brown, J.K. The previously unidentified, divergent badnavirus species Cacao red vein-banding virus is associated with Cacao swollen shoot disease in Nigeria. Plant Dis. 2019, 103, 1302-1308. [CrossRef]

16. Ding, S.-W.; Mackenzie, A.; Torronen, M.; Gibbs, A. Nucleotide sequence of the virion protein gene of cacao yellow mosaic tymovirus. Nucleic Acids Res. 1990, 18, 5886. [CrossRef] [PubMed]

17. Kenten, R. The purification and some properties of cocoa necrosis virus, a serotype of tomato black ring virus. Ann. Appl. Biol. 1972, 71, 119-126. [CrossRef] 
18. Brunt, A.; Kenten, R.; Gibbs, A.; Nixon, H. Further studies on cocoa yellow mosaic virus. Microbiology 1965, 38, 81-90. [CrossRef] [PubMed]

19. Muller, E.; Sackey, S. Molecular variability analysis of five new complete cacao swollen shoot virus genomic sequences. Arch. Virol. 2005, 150, 53-66. [CrossRef]

20. Kumar, S.; Stecher, G.; Li, M.; Knyaz, C.; Tamura, K. MEGA X: Molecular evolutionary genetics analysis across computing platforms. Mol. Biol. Evol. 2018, 35, 1547. [CrossRef]

21. Edgar, R.C. MUSCLE: Multiple sequence alignment with high accuracy and high throughput. Nucleic Acids Res. 2004, 32, 1792-1797. [CrossRef]

22. Hall, B.G. Building phylogenetic trees from molecular data with MEGA. Mol. Biol. Evol. 2013, 30, 1229-1235. [CrossRef] [PubMed]

23. Tamura, K. Estimation of the number of nucleotide substitutions when there are strong transition-transversion and $\mathrm{G}+\mathrm{C}$-content biases. Mol. Biol. Evol. 1992, 9, 678-687. [PubMed]

24. Baker, R.; Dale, W. Virus diseases of cacao in Trinidad II. Trop. Agric. 1947, 24, 127-130.

25. Kirkpatrick, T. Insect Pests of Cacao and Insect Vectors of Cacao Virus Disease. Rep. Cacao Res. 1953, 5, $122-125$. 